\title{
Oxygen Radical Scavengers Selectively Inhibit Interleukin 8 Production in Human Whole Blood
}

\author{
Laura E. DeForge, Joseph C. Fantone, John S. Kenney, ${ }^{*}$ and Daniel G. Remick \\ Department of Pathology, University of Michigan Medical School, Ann Arbor, Michigan 48109-0602; and \\ *Department of Cellular Immunology, Syntex Research, Inc., Palo Alto, California 94304
}

\begin{abstract}
The hydroxyl radical $\left(\mathrm{OH}^{\circ}\right)$ scavenger dimethyl sulfoxide (DMSO) was found to dose-dependently inhibit interleukin 8 (IL-8) production in LPS-stimulated human whole blood. At a concentration of $1 \%$ ( vol / vol ), DMSO blocked $\mathrm{IL}-8$ release by $\sim 90 \%$ in the presence of $1 \mu \mathrm{g} / \mathrm{ml}$ LPS at a 24-h time point, but did not affect cell viability or reduce the production of tumor necrosis factor (TNF), interleukin 6, or interleukin-1 $\beta$ (IL$1 \beta)$. DMSO was found to directly inhibit IL-8 expression at the level of transcription. Furthermore, this effect was not LPS-specific, in that IL-8 production was reduced by DMSO to a similar extent upon stimulation of blood with phytohemagglutinin, aggregated immune complexes, TNF, or IL-1 $\beta$. Other oxygen radical scavengers that have been shown to inhibit $\mathrm{OH}^{\circ}$-dependent reactions (dimethyl thiourea, thiourea, mannitol, and ethanol) also inhibited IL-8 production. Conversely, addition of $\mathrm{H}_{2} \mathrm{O}_{2}$ caused a dose-dependent stimulation of IL-8 release. These results provide evidence that reactive oxygen metabolites play an important role in the regulation of IL-8 production and suggest that reduction of $I L-8$ release may contribute to the beneficial effects of antioxidants in experimental models of inflammation and ischemia/reperfusion injury. (J. Clin. Invest. 1992. 90:2123-2129.) Key words: dimethyl sulfoxide • interleukin 6 • interleukin $1 \beta$ • tumor necrosis factor • whole blood
\end{abstract}

\section{Introduction}

Interleukin 8 (IL-8) is a member of a recently described family of low molecular weight cytokines. This neutrophil chemoattractant/activator is produced by a wide variety of cell types, including monocytes, endothelial cells, and fibroblasts $(1,2)$. Its production is elicited by inflammatory stimuli such as lipopolysaccharide (LPS) and phytohemagglutinin (PHA), as well as by proinflammatory cytokines, specifically tumor necrosis

Portions of this work have appeared in abstract form (1992. FASEB J. 6:A1429).

Address reprint requests to Dr. Remick, M2210 Medical Sciences I, Department of Pathology, University of Michigan Medical School, Ann Arbor, MI 48109-0602. 1992.

Received for publication 20 April 1992 and in revised form 18 June

J. Clin. Invest.

(C) The American Society for Clinical Investigation, Inc.

$0021-9738 / 92 / 11 / 2123 / 07 \quad \$ 2.00$

Volume 90, November 1992, 2123-2129 factor (TNF) 1 and interleukin $1 \beta(\operatorname{IL}-1 \beta)(1,2)$. Although the presence of IL-8 has been detected in several disease states (310 ), it is presently unclear what role IL-8 plays in attracting neutrophils to tissue sites in vivo. This issue is of considerable importance as newly recruited neutrophils are capable of mediating extensive tissue damage. This has been particularly well established in experimental models of ischemia/reperfusion injury (11-15). In such models, reactive oxygen intermediates (ROI), produced upon reoxygenation of ischemic tissue, appear to be a critical component of the injury process. They not only directly contribute to the tissue damage (16-19), but also initiate neutrophil recruitment by causing the production of various neutrophil chemotactic factors (20-22). These observations have led us to investigate whether ROI may mediate IL-8 production.

Human whole blood was used in these studies as an ex vivo model of local cytokine production (23-25). By retaining the integrity of this tissue system, the leukocytes are maintained in their physiologic environment, cellular interactions are preserved, and potential artifacts resulting from adherence or lengthy isolation procedures are avoided. This model has been extensively used in our laboratory (23-25), as well as by multiple other investigators (26-30). In the present report, we demonstrate that oxygen radical scavengers dramatically inhibit production of IL-8 in LPS-stimulated human whole blood.

\section{Methods}

Reagents. LPS (Escherichia coli 0111:B4), DMSO, PHA, superoxide dismutase (SOD), catalase, deferoxamine, allopurinol, thiourea (TU), mannitol, and hydrogen peroxide $\left(\mathrm{H}_{2} \mathrm{O}_{2}\right)$ were obtained from Sigma Chemical Co., St. Louis, MO. Dimethyl thiourea (DMTU) was purchased from Aldrich Chemical Co., Milwaukee, WI. Human recombinant TNF and IL-1 $\beta$ were gifts from Cetus Immune Corp., Palo Alto, $\mathrm{CA}$, and the Upjohn Co., Kalamazoo, MI, respectively. Endotoxin-free aggregated immune complexes were prepared as previously described (31) and were generously provided by Brian Wharram.

Experimental design. Experiments were performed essentially as described (24). Briefly, blood from normal male volunteers was drawn into heparinized syringes ( $20 \mathrm{U}$ heparin $/ \mathrm{ml}$ ), and $1-\mathrm{ml}$ aliquots were placed in sterile $1.5-\mathrm{ml}$ centrifuge tubes. As required, ROI scavengers and LPS (using a $200 \mu \mathrm{g} / \mathrm{ml}$ stock solution) were added to the aliquots. The blood was then placed on a rotator and incubated at $37^{\circ} \mathrm{C}$ in a humidified atmosphere containing $5 \% \mathrm{CO}_{2}$. At the designated time point, samples were removed from the incubator and immediately cen-

1. Abbreviations used in this paper: $\mathrm{CHX}$, cycloheximide; DMTU, dimethyl thiourea; IC, immune complex (es); ROI reactive oxygen intermediates; TNF, tumor necrosis factor; TU, thiourea. 
trifuged at $600 \mathrm{~g}$ for $5 \mathrm{~min}$. The plasma was then removed, diluted 1:5 with RPMI 1640 media (Gibco Laboratories, Grand Island, NY) containing $1 \%$ fetal bovine serum (FBS), and stored at $-20^{\circ} \mathrm{C}$ for later cytokine analysis. For some samples, the buffy coat was removed from the top of the packed red blood cells and contaminating red cells were lysed with $0.82 \% \mathrm{NH}_{4} \mathrm{Cl}$. The white blood cells were pelleted by centrifugation and dissolved in $0.3 \mathrm{ml}$ of an RNA extraction buffer $(25 \mathrm{mM}$ Tris, $\mathrm{pH} 8.0,4.2 \mathrm{M}$ guanidine isothiocyanate, $0.5 \% \mathrm{~N}$-laurosarcosine, and $0.1 \mathrm{M} 2$-mercaptoethanol). The samples were stored at $-70^{\circ} \mathrm{C}$ for later processing.

White blood cell $(W B C)$ viability. Viability studies were performed as described (25). Aliquots of blood left unstimulated or stimulated with LPS in the presence of increasing concentrations of DMSO were incubated as described above for $24 \mathrm{~h}$. The buffy coat was then isolated, subjected to $\mathrm{NH}_{4} \mathrm{Cl}$ lysis twice to completely clear red blood cell contamination, and resuspended in $1 \mathrm{ml}$ RPMI containing $1 \%$ FBS, 100 $\mathrm{U} / \mathrm{ml}$ penicillin, $100 \mu \mathrm{g} / \mathrm{ml}$ streptomycin, $1 \mathrm{mM}$ L-glutamine, $25 \mathrm{mM}$ Hepes, and $50 \mu \mathrm{M} 2$-mercaptoethanol. Triplicate aliquots of the cell suspension $(200 \mu \mathrm{l})$ were placed in 96-well plates, and $20 \mu \mathrm{l}$ MTT-tetrazolium $(5 \mathrm{mg} / \mathrm{ml}$, Sigma Chemical Co.) was added. This reagent is metabolized to a dark blue end product only by live cells and thereby provides a rapid, accurate means of determining cell viability in a large number of samples (32). The plates were incubated for $4 \mathrm{~h}$ at $37^{\circ} \mathrm{C}$ in a humidified atmosphere containing $5 \% \mathrm{CO}_{2} .150 \mu \mathrm{l}$ of the supernatant was then removed, $100 \mu \mathrm{l}$ of $0.04 \mathrm{~N} \mathrm{HCl}$ /isopropanol was added to solubilize the blue crystals, and the plates were allowed to stand overnight protected from light. The absorbance at $550 \mathrm{~nm}$ was measured using a Bio-Tek microplate reader (Bio-Tek Instruments, Inc., Winoos$\mathrm{ki}, \mathrm{VT}$ ).

TNF and IL-6 assays. Plasma TNF levels were measured as previously described $(33,34)$ using the WEHI 164 subclone 13 cell line, the gift of Dr. Anders Waage, University of Trondheim, Norway. The B-9 cell line was used to assess plasma IL- 6 concentrations $(24,35)$. TNF and IL- 6 concentrations were calculated based on a standard curve of serially diluted human recombinant TNF (Cetus) or human recombinant IL-6 (PeproTech, Inc., Rocky Hill, NJ). Control studies indicated that relevant concentrations of DMSO did not affect the ability of these assays to measure TNF or IL-6.

IL-8 assay. The plasma IL-8 concentrations were determined by ELISA (36) using native and biotinylated rabbit polyclonal anti-IL-8 antibody as the capture and secondary antibodies, respectively. Horseradish peroxidase-conjugated avidin (Dako, Corp., Carpinteria, CA) and $o$-phenylenediamine tablets (Dako Corp.) were used for color development. The lower limity of sensitivity of the assay was typically $<80 \mathrm{pg} / \mathrm{ml}$. Connective tissue activating peptide III, platelet factor 4, neutrophil activating peptide 2 , and melanoma growth stimulating activity were not detectable in this assay. The presence of DMSO had no effect on the ability of this ELISA to reliably detect IL-8.

$I L-I \beta$ assay. Plasma IL- $1 \beta$ levels were measured using an ELISA as described (37). ILB1-H6 and biotinylated ILB1-H67 were the monoclonal antibodies used as capture and secondary antibodies, respectively. The color development reagents were horseradish peroxidaseconjugated streptavidin (Zymed, South San Francisco, CA) and $a$ phenylenediamine tablets (Zymed). This assay was typically sensitive to $<50 \mathrm{pg} / \mathrm{ml}$ using KinetiCalc software (Bio-Tek Instruments, Inc.)

Northern blot analysis. Total RNA was extracted from the WBC pellets and mRNA levels were assessed by Northern blot analysis using our previously described techniques (24). The blots were hybridized with the ${ }^{32} \mathrm{P}-5^{\prime}$ end-labeled 30-mer oligonucleotide for IL-8 5'-GTT GGC-GCA-GTG-TGG-TCC-ACT-CTC-AAT-CAC-3' (38). The blots were washed and autoradiographed with intensifying screens. The blots were then stripped (by heating at $80^{\circ} \mathrm{C}$ in a $1 \%$ glycerol solution for 1 $h$ ), reprobed with the ${ }^{32} \mathrm{P}-5^{\prime}$ end-labeled 42-mer oligonucleotide for $\beta$-actin, 5'-GGC-TGG-GGT-GTT-GAA-GGT-CTC-AAA-CAT-GATCTG-GGT-CAT-CTT-3' (39), and autoradiographed. All autoradiograms were scanned with an image analysis system (AMBIS, San Diego, CA) to quantitate the relative intensities of the bands. For each blot, the results were normalized to represent equivalent RNA loading in each lane based on the intensity of the actin bands, and the intensity of each lane was then expressed as a percentage of the intensity of the darkest band of each blot.

Statistical analyses. The significance of the difference between groups was assessed by Student's $t$ test for single comparisons and by Student-Newman-Keuls test for multiple comparisons.

\section{Results}

Initial studies to evaluate the role of reactive oxygen intermediates in inducing IL-8 expression were performed using DMSO, a known $\mathrm{OH}^{\bullet}$ scavenger (40). DMSO was chosen because it has low toxicity, it has been found to have beneficial effects in a wide range of disease models, and it possesses chemical properties which allow it to readily penetrate cell membranes $(41,42)$. A dose-response study was performed in which DMSO over a final concentration range of $0.008-5 \%$ was added to LPS-stimulated $(1 \mu \mathrm{g} / \mathrm{ml})$ whole blood from five normal male volunteers. At the 24-h time point, plasma was harvested and analyzed for IL-8 using a specific ELISA. The results for each donor were expressed as a percentage of the IL-8 release measured in the presence of LPS alone, and the compiled results represent mean \pm SEM for five donors. Fig. $1 A$ demonstrates that DMSO caused a dose-dependent reduction in IL-8 release. The markedly suppressed levels of IL-8 release observed at DMSO concentrations of $0.04 \%, 0.2 \%, 1 \%$, and $5 \%$ were significantly different from the levels of IL-8 measured in the presence of $0.008 \%$ DMSO $(P<0.05$, Student-NewmanKeuls test). An $\mathrm{EC}_{50}$ of $0.08 \%$ was calculated from these results. Cell viability studies showed that leukocyte viability was unaffected by the presence of DMSO at concentrations $\leq 1 \%$ (data not shown). A profound reduction in IL-8 release was evident in the samples containing 1\% DMSO, with IL-8 levels amounting to only $8.9 \pm 1.2 \%$ (mean \pm SEM, $n=5$ ) of the samples incubated with LPS alone. This concentration was therefore chosen for use in further studies.

The effect of $1 \%$ DMSO on the time course of IL- 8 production was also evaluated (Fig. $1 B$ ). In the presence of LPS alone $(1 \mu \mathrm{g} / \mathrm{ml})$, plasma IL-8 levels were observed to increase in a biphasic pattern. This extremely reproducible profile of release has been documented in our laboratory $(23,24)$. Previous studies have shown that the secondary phase of IL-8 production occurring between 12 and $24 \mathrm{~h}$ is completely inhibitable by the addition of neutralizing anti-TNF and anti-IL-1 antibodies (24). The early phase of IL-8 production ( $2-12 \mathrm{~h}$ ) is unaffected by the presence of these antibodies, suggesting it is an LPS-mediated response. Interestingly, DMSO significantly reduced IL8 production over the entire time course, indicating that its mechanism of inhibition was quite different from that of the anti-cytokine antibodies. DMSO treatment suppressed LPSdependent IL-8 production by $39.6 \pm 9.5 \%$ and $90.7 \pm 1.0 \%$ (mean \pm SEM, $n=5$ ) at 6 and $24 \mathrm{~h}$, respectively.

To determine whether the DMSO-induced reduction in LPS-dependent IL-8 production was occurring at the level of transcription or translation, Northern blot analysis was performed on RNA extracted from the buffy coats of blood samples incubated for $3 \mathrm{~h}$ with LPS $(1 \mu \mathrm{g} / \mathrm{ml})$ in the presence and absence of $1 \%$ DMSO. A significant reduction in LPS-stimulated IL-8 mRNA levels was observed upon incubation with DMSO (Fig. 2). To test whether the reduction in IL-8 transcription was a direct effect or dependent on the synthesis of an intermediary protein, experiments were performed with the 


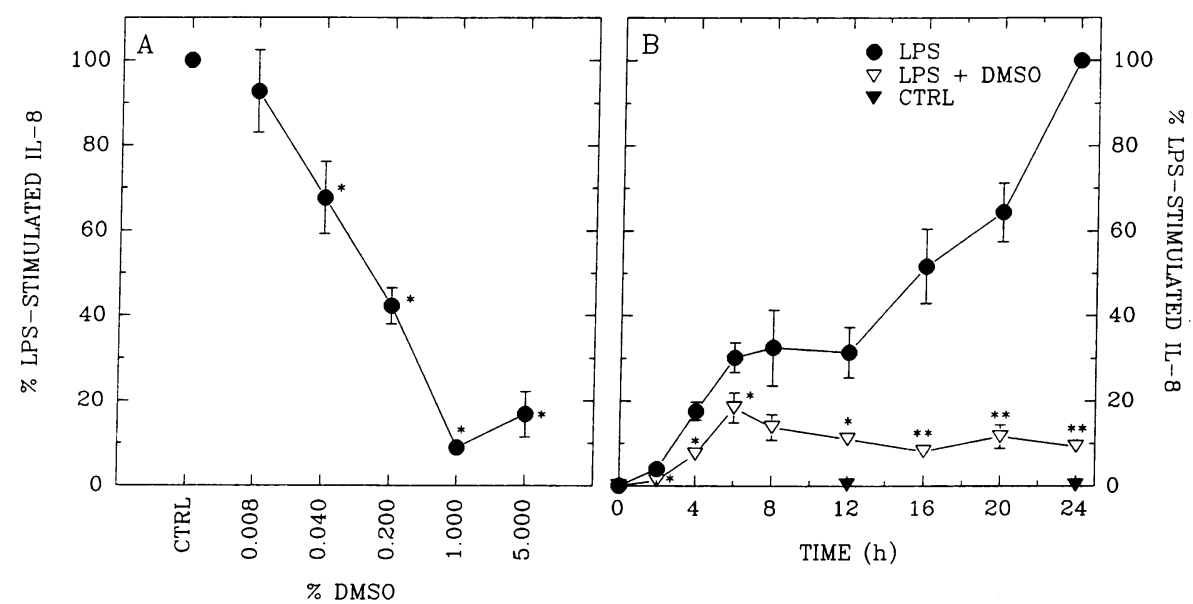
from the samples at the same time point incubated with LPS alone $\left({ }^{*} P<0.05 ;{ }^{*} P<0.001\right.$, Student's $t$ test $)$. For both graphs, symbols indicate mean \pm SEM for five individual blood donors, with the results for each donor being expressed as a percentage of the 24-h IL-8 production observed in the presence of LPS alone.

protein synthesis inhibitor cycloheximide $(\mathrm{CHX})$. Blood samples were incubated with LPS + CHX $(5 \mu \mathrm{g} / \mathrm{ml})$ or LPS + DMSO + CHX. IL-8 mRNA was similarly suppressed by DMSO under these conditions indicating that DMSO has a direct inhibitory effect. As previously noted (1), superinduction of IL-8 mRNA was evident in the presence of cycloheximide.

The effect of DMSO on the production of other cytokines was also evaluated. The results shown in Fig. 3 are representative of more than four experiments and demonstrate that the inhibitory effect of DMSO was highly specific for IL-8. The presence of $1 \%$ DMSO had no effect on the release of TNF. IL- $1 \beta$ and IL- 6 concentrations, however, were elevated in the presence of DMSO. This trend did not reach statistical significance in the case of IL- $1 \beta$, but IL- 6 levels were significantly increased at nearly every time point $(P<0.05$, Student's $t$ test $)$.

To determine whether this profound reduction in IL-8 release by DMSO is a generalized phenomenon or specific to an LPS stimulus, the ability of DMSO to block IL-8 production in the presence of other stimuli was addressed. The additional agents included PHA, $10 \mu \mathrm{g} / \mathrm{ml}$; endotoxin-free aggregated immune complexes (IC), $250 \mu \mathrm{g} / \mathrm{ml}$; TNF, $370 \mathrm{ng} / \mathrm{ml}$; and IL$1 \beta, 100 \mathrm{ng} / \mathrm{ml}$ ( Table I). Each of these stimuli elicited production of substantial concentrations of IL-8 $(10 \mathrm{ng} / \mathrm{ml}$ or greater). Addition of DMSO reduced plasma IL-8 levels by 86-97\% for all stimuli.

In all of the preceding studies, DMSO has been used as a prototypical scavenger of $\mathrm{OH}^{\bullet}$. Further studies were performed to determine whether other compounds classically used as ROI scavengers were capable of mediating a similar effect (Table II). DMTU, reported to be a $\mathrm{H}_{2} \mathrm{O}_{2}$ scavenger by some investigators (43) and a $\mathrm{OH}^{\bullet}$ scavenger by others (44), equaled or exceeded the ability of DMSO to reduce plasma IL-8 levels. TU, a scavenger of both $\mathrm{OH}^{\bullet}$ and $\mathrm{H}_{2} \mathrm{O}_{2}(45)$, also profoundly inhibited IL-8 release, while mannitol and ethanol were typically somewhat less efficacious (40). Other agents, however, were ineffective in reducing IL-8 production. These include catalase and SOD, enzymes which metabolize $\mathrm{H}_{2} \mathrm{O}_{2}$ and superoxide anion $\left(\mathrm{O}_{2}^{-}\right)$, respectively; deferoxamine, an iron chelator purported to reduce $\mathrm{OH}^{\bullet}$ production from $\mathrm{O}_{2}^{-}$and $\mathrm{H}_{2} \mathrm{O}_{2}$ via
Figure 1. A. DMSO dose-dependently inhibited IL-8 production in LPS-stimulated blood. Increasing concentrations of DMSO were added to blood stimulated with $1 \mu \mathrm{g}$ / $\mathrm{ml}$ LPS. The blood was incubated on a rotator at $37^{\circ} \mathrm{C}$, and plasma was harvested at $24 \mathrm{~h}$ for analysis in the IL-8 ELISA. Significant differences $(P<0.05$, StudentNewman-Keuls test) from the samples containing $0.008 \%$ DMSO are indicated with an asterisk $\left({ }^{*}\right)$. B. Time course of IL-8 production in the presence and absence of DMSO. DMSO ( $1 \%$ ) was added to LPS-stimulated $(1 \mu \mathrm{g} / \mathrm{ml})$ blood, and samples were harvested at the indicated time points for measurement of plasma IL-8 levels. The control samples received no additions. The asterisks indicate a significant 


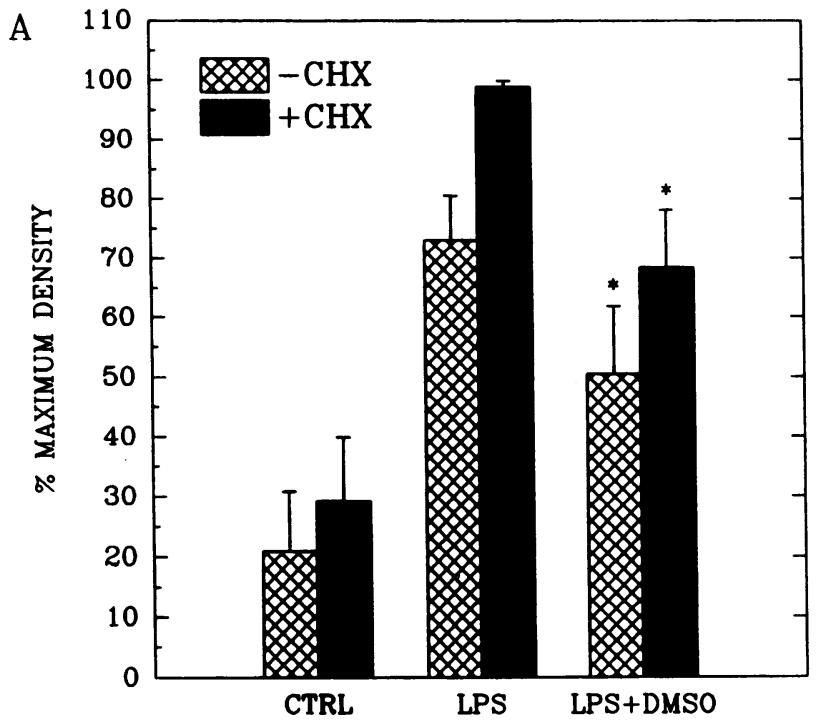

B

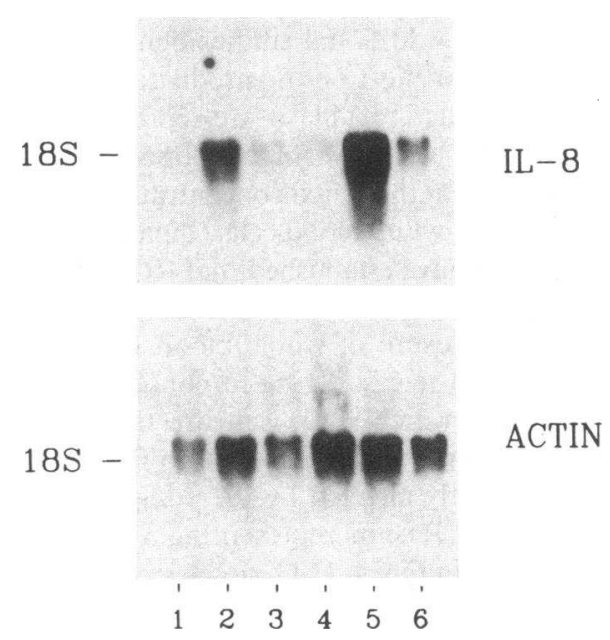

Figure 2. DMSO reduces LPS-stimulated IL-8 mRNA expression in the absence $(-\mathrm{CHX})$ and presence $(+\mathrm{CHX})$ of cycloheximide. LPS-stimulated $(1 \mu \mathrm{g} / \mathrm{ml})$ blood was incubated for $3 \mathrm{~h} \pm 1 \%$ DMSO and $\pm 5 \mu \mathrm{g} / \mathrm{ml}$ cycloheximide. $(A)$ Results of autoradiogram densitometric analysis. Autoradiograms of the same blots probed sequentially for IL-8 and actin were scanned. The IL-8 results were adjusted based on the actin blots to represent equivalent RNA loading in each lane, and the results were then expressed as a percentage of the band of maximal intensity for each blot. The final results represent mean \pm SEM of blots from five individual blood donors. Asterisks $\left({ }^{*}\right)$ represent a statistically significant $(P<0.05)$ difference from the samples incubated with LPS alone. $(B)$ Autoradiograms of a representative blot probed for actin and IL-8. Lane 1, ctrl; lane 2, LPS; lane 3, LPS + DMSO; lane 4, ctrl + CHX; lane 5, LPS + CHX; lane 6. LPS + DMSO + CHX.

weight proteins to cross cell membranes (49-51). In addition, the lack of effect of allopurinol suggests that xanthine oxidase does not substantially contribute to ROI production in this model. Lastly, although the ability of DMSO to reduce IL-8 release suggests the involvement of $\mathrm{OH}^{\bullet}$, deferoxamine had no inhibitory effect and actually increased IL-8 production in some instances (Table II). The failure of deferoxamine to re- duce IL-8 may potentially be explained by the limited cellular uptake of deferoxamine and the high iron binding capacity of plasma which limits the availability of free iron (52). The ability of cell membrane permeable scavengers and the inability of nonpermeable agents to reduce IL-8 expression suggest that the intracellular localization of reactive oxygen intermediates may play a key role in the induction of IL-8. This possibility is strongly supported by corollary experiments in which direct addition of $\mathrm{H}_{2} \mathrm{O}_{2}$, a freely diffusable molecule, to whole blood caused a dose-dependent stimulation of IL-8 production.

ROI and neutrophils have been shown to contribute to the tissue injury following ischemia/reperfusion (11-19). A link between these injurious agents was established with the observation that ROI result in the generation of neutrophil chemo-

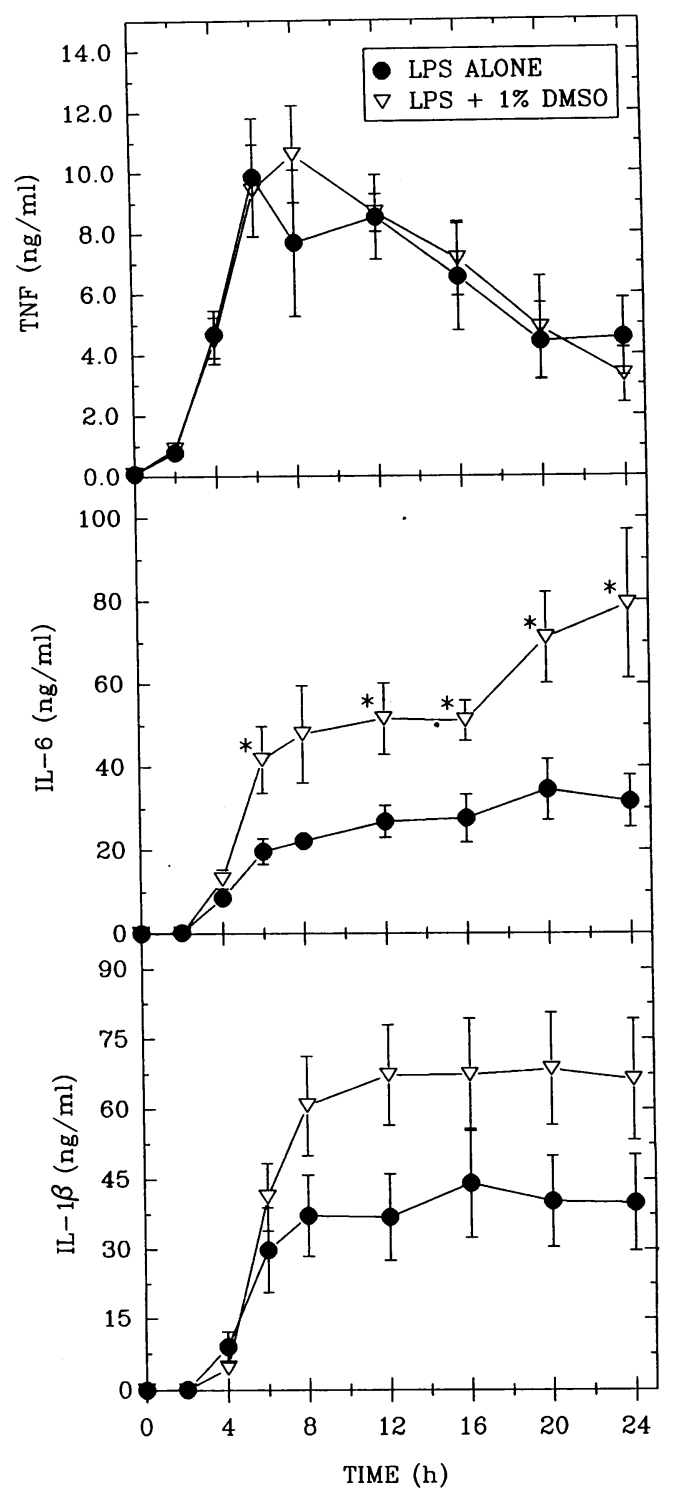

Figure 3. Effect of DMSO ( $1 \% \mathrm{vol} / \mathrm{vol})$ on the production of TNF, IL-6, and IL- $1 \beta$ in LPS-stimulated human whole blood. Blood was obtained from five normal volunteers and stimulated with $1 \mu \mathrm{g} / \mathrm{ml}$ LPS in the presence of $1 \%$ DMSO. The samples were then incubated at $37^{\circ} \mathrm{C}$, and at the indicated time points, the plasma was harvested and analyzed for TNF, IL-6, and IL-1 $\beta$. The results represent mean $\pm \operatorname{SEM}(n=5) .{ }^{*} P<0.05$, Student's $t$ test. 
Table I. Ability of DMSO to Inhibit IL-8 Production Elicited by Different Stimuli

\begin{tabular}{|c|c|c|c|c|}
\hline \multirow[b]{2}{*}{ Stimulus } & \multirow[b]{2}{*}{ Concentration } & \multicolumn{2}{|c|}{ IL-8 } & \multirow{2}{*}{$\begin{array}{l}\text { Percentage } \\
\text { of stimulus } \\
\text { alone }\end{array}$} \\
\hline & & Stimulus alone & Stimulus + DMSO & \\
\hline & \multicolumn{4}{|c|}{$n g / m l$} \\
\hline LPS & $1 \mu \mathrm{g} / \mathrm{ml}$ & $10.00 \pm 2.98$ & $1.76 \pm 1.00^{*}$ & $13.6 \pm 3.8$ \\
\hline PHA & $10 \mu \mathrm{g} / \mathrm{ml}$ & $14.72 \pm 3.90$ & $1.97 \pm 0.99 *$ & $12.1 \pm 4.0$ \\
\hline IC & $250 \mu \mathrm{g} / \mathrm{ml}$ & $65.82 \pm 17.32$ & $0.85 \pm 0.31^{\ddagger}$ & $1.4 \pm 0.3$ \\
\hline TNF & $370 \mathrm{ng} / \mathrm{ml}$ & $12.49 \pm 3.53$ & $0.93 \pm 0.07^{*}$ & $18.1 \pm 9.7$ \\
\hline IL-1 $\beta$ & $100 \mathrm{ng} / \mathrm{ml}$ & $27.25 \pm 4.97$ & $1.40 \pm 0.28^{\ddagger}$ & $6.3 \pm 1.5$ \\
\hline
\end{tabular}

DMSO at a concentration of $1 \%$ was able to effectively inhibit production of IL-8 regardless of the stimulus. For all stimuli, plasma was obtained $24 \mathrm{~h}$ after stimulation. Asterisks indicate a significant difference from the samples incubated with stimulus alone as assessed by Student's $t$ test $\left({ }^{*} P<0.05 ;{ }^{\ddagger} P<0.01\right)$.

tactic factors. These include a chloroform extractable, albumin-associated factor generated by treating plasma with $\mathrm{O}_{2}^{-}$ (20); an arachidonic acid metabolite produced upon incubation with xanthine oxidase (21); and a $\mathrm{C}_{5 \mathrm{a}}$-like chemoattractant generated by $\mathrm{H}_{2} \mathrm{O}_{2}(22)$. Such factors may constitute an important amplifying mechanism in the initiation of reperfusion injury leading to the recruitment of neutrophils which further augment tissue injury by the release of proteases and NADPH-oxidase generated oxygen radicals (53). The induction of IL-8, however, may have a greater biologic impact than that of other neutrophil chemotactic factors. While $\mathrm{C}_{5 \mathrm{a}}$ and $\mathrm{LTB}_{4}$ have been shown to be relatively short-lived $(54,55)$, IL-8 persists for much longer periods of time and is remarkably stable in the presence of proteases $(1,2)$. Antibody neutraliza-

Table II. Effect of Other Antioxidants and Free Radical Scavengers on LPS-Stimulated IL-8 Production

\begin{tabular}{lcc}
\hline \multicolumn{1}{c}{ Treatment } & Concentration & $\begin{array}{c}\text { Percentage of } \\
\text { LPS-stimulated } \\
\text { IL-8 }\end{array}$ \\
\hline DMSO & $1 \%$ & $11.9 \pm 3.5^{* \ddagger}$ \\
DMTU & $75 \mathrm{mM}$ & $0 \pm 0^{\ddagger}$ \\
TU & $75 \mathrm{mM}$ & $25.1 \pm 6.2^{\ddagger}$ \\
Mannitol & $50 \mathrm{mM}$ & $59.1 \pm 11.2^{\ddagger}$ \\
Ethanol & $0.5 \%$ & $16.1 \pm 3.0^{\ddagger}$ \\
Allopurinol & $5 \mathrm{mM}$ & $138.4 \pm 37.4$ \\
Catalase & $1,500 \mathrm{U} / \mathrm{ml}$ & $124.8 \pm 68.6$ \\
SOD & $1,000 \mathrm{U} / \mathrm{ml}$ & $106.2 \pm 26.2$ \\
Deferoxamine & $1 \mathrm{mM}$ & $199.0 \pm 36.9$ \\
& & \\
\hline
\end{tabular}

LPS-dependent IL-8 production was significantly decreased by $\mathrm{OH}^{\bullet}$ scavengers, but not by the other agents tested.

* The data shown (mean \pm SEM, $n=5$ ) is representative of at least three experiments with five blood donors each. None of the reagents used at the above concentrations reduced cell viability.

${ }^{\ddagger}$ Denotes a significant difference $(P<0.05)$ between the levels of IL-8 measured in the treated samples and samples stimulated with LPS alone. Student's $t$ test was used for single comparisons and StudentNewman-Keuls test was used for multiple comparisons, against the same LPS-stimulated group.

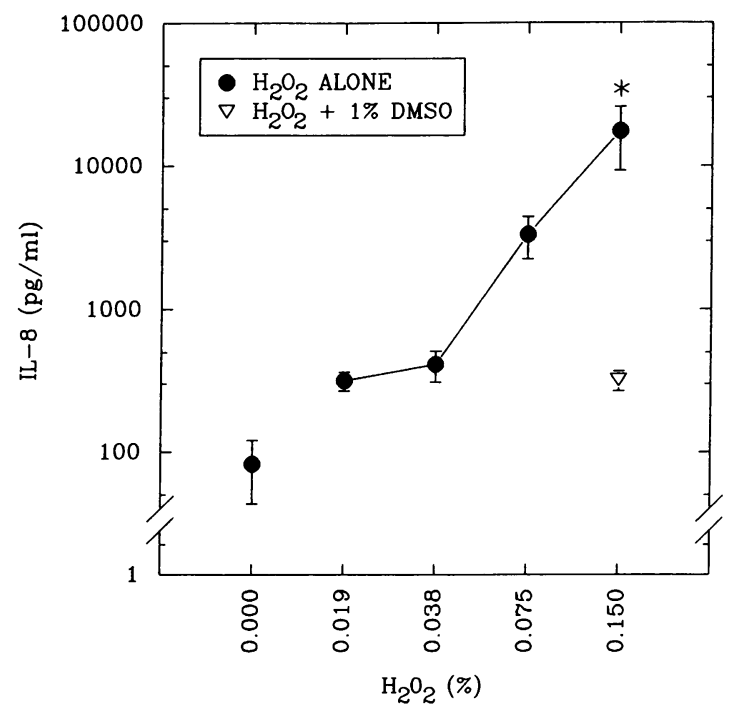

Figure 4. $\mathrm{H}_{2} \mathrm{O}_{2}$ dose-dependently stimulated IL-8 production in human whole blood. The blood was either left unstimulated or $\mathrm{H}_{2} \mathrm{O}_{2}$ was directly added at the indicated concentrations. $1 \%$ DMSO was also added to samples containing the highest concentration of $\mathrm{H}_{2} \mathrm{O}_{2}$. The plasma was harvested after a 24-h incubation period and analyzed in the IL-8 ELISA. These results (mean \pm SEM) represent a compilation of two separate experiments with a total of nine donors. ${ }^{*} P<0.05$ compared to all other data points (Student-Newman-Keuls test).

tion studies in our laboratory have shown that the neutrophil chemotactic activity present in the plasma of whole blood incubated with LPS for $24 \mathrm{~h}$ is almost completely attributable to IL-8 (24).

Although emphasis has been placed on the relevance of ROI to ischemia/reperfusion injury, oxygen radicals may play a significant role in many other disease processes such as arthritis, atherosclerosis, and adult respiratory distress syndrome (52). Whereas LPS and the other soluble inflammatory mediators used in these studies cannot be directly compared to the conditions accompanying ischemia/reperfusion, all stimuli employed in these studies have been demonstrated to result in the formation of oxygen radicals. This has been particularly well characterized for phagocytic cells (56-61) but appears to be a more generalized phenomenon. Superoxide production has been observed to occur in endothelial cells in response to IL-1 $\beta$ and interferon- $\gamma(62)$, in fibroblasts in response to IL- $1 \alpha$ and TNF (63), in chondrocytes and synovial cells in response to TNF (64).

DMSO has been used clinically as an anti-inflammatory agent in arthritis and other disease states $(41,42)$. The present studies suggest that inhibition of IL-8 production may, in part, have contributed to its beneficial effects. Additional anti-inflammatory properties of DMSO that have been recently discovered include its ability to prevent adhesion of neutrophils to endothelium (65), to scavenge hypochlorous anion (66), and possibly to reduce NADPH-oxidase activity (66). Pretreatment with DMTU reduced the chemotatic activity in the plasma of sheep injected with endotoxin, demonstrating the in vivo efficacy of the membrane permeable scavengers (67). Of the cytokines measured in this study, the inhibitory effect of DMSO was highly specific for IL-8. While TNF levels were unaffected by DMSO, IL- $1 \beta$ release tended to be elevated and 
IL-6 concentrations were significantly increased. Although the importance of these changes is unclear, the elevation in IL-6 levels may potentially represent a protective effect induced by DMSO. IL-6 is known to enhance host immune functions and induce the acute phase response.

In conclusion, these studies provide convincing evidence that endogenously produced ROI directly induce the transcription and translation of IL-8. The results suggest that the ability of oxygen radical scavengers to inhibit ischemia/reperfusion injury and inflammation may be, in part, secondary to a decrease in local production of IL-8 and a subsequent reduction in elicitation of neutrophils.

\section{Acknowledgments}

The authors wish to acknowledge Gerald Bolgos and Tony Cardellio for their technical assistance and Camille Hughes for her secretarial support.

This research was supported by grants GM-44918 and DK-42455 from the National Institutes of Health.

\section{References}

1. Oppenheim, J. J., C. O. C. Zachariae, N. Mukaida, and K. Matsushima 1991. Properties of the novel proinflammatory supergene "intercrine" cytokine family. Ann. Rev. Immunol. 9:617-648.

2. Baggiolini, M., A. Walz, and S. L. Kunkel. 1989. Neutrophil-activating peptide-1/interleukin 8 , a novel cytokine that activates neutrophils. $J$. Clin. In vest. 84:1045-1049.

3. Van Zee, K. J., L. E. DeForge, E. Fischer, M. A. Marano, J. S. Kenney, D. G. Remick, S. F. Lowry, and L. L. Moldawer. 1991. IL-8 in shock, endotoxemia, and following IL-1 administration. J. Immunol. 146:3478-3482.

4. Martich, G. D., R. L. Danner, M. Ceska, and A. F. Suffredini. 1991. Detection of interleukin 8 and tumor necrosis factor in normal humans after intravenous endotoxin: the effect of anti-inflammatory agents. J. Exp. Med. 173:10211024.

5. Danner, R. L., A. F. Suffredini, A. L. Van Dervort, M. Ceska, P. L. Stuetz, J. A. Zablotny, and E. A. Patterson. 1990. Dection of interleukin 6 (IL-6) and interleukin 8 (IL-8) during septic shock in humans. Clin. Res. 38:352A. (Abstr.)

6. Brennan, F. M., C. O. C. Zachariae, D. Chantry, C. G. Larsen, M. Turner, K. Maini, K. Matsushima, and M. Feldman. 1990. Detection of interleukin 8 biological activity in synovial fluids from patients with rheumatoid arthritis and production of interleukin $8 \mathrm{mRNA}$ by isolated synovial cell. Eur. J. Immunol. 20:2141-2144.

7. Nickoloff, B. J., G. D. Karabin, J. N. W. N. Barker, C. E. M. Griffiths, V. Sarma, R. S. Mitra, J. T. Elder, S. L. Kunkel, and V. M. Dixit. 1991. Cellular localization of interleukin-8 and its inducer, tumor necrosis factor-alpha in psoriasis. Am. J. Pathol. 138:129-140.

8. Garner, W. L., J. L. Rodriguez, C. Miller, D. J. Smith, and D. G. Remick 1991. Acute skin injury releases neutrophil chemoattractants. Surg. Forum. 42:617-618

9. Rodriguez, J. L., C. Miller, L. E. DeForge, C. Shanley, D. G. Remick, and R. H. Bartlett. 1992. Local production of interleukin-8 is associated with nosocomial pneumonia. J. Trauma. 33:74-82.

10. Remick, D. G., L. E. DeForge, J. F. Sullivan, and H. J. Showell. 1992. Profile of cytokines in synovial fluid specimens from patients with arthritis: interleukin-8 (IL-8) and IL-6 correlate with inflammatory arthritides. Immunol. Invest. $21: 321-327$.

12. Simpson, P. J., R. F. Todd, III, J. C. Fantone, J. K. Mickelson, J. D. Griffin, and B. R. Lucchesi. 1988. Reduction of experimental canine myocardial reperfusion injury by a monoclonal antibody (anti-Mol, anti-CD11b) that inhibits leukocyte adhesion. J. Clin. Invest. 81:624-629.

13. Vedder, N. B., R. K. Winn, C. L. Rice, E. Y. Chi, K.-E. Arfors, and J. M. Harlan. 1988. A monoclonal antibody to the adherence-promoting leukocyte glycoprotein, CD18, reduces organ injury and improves survival from hemorrhagic shock and resuscitation in rabbits. J. Clin. Invest. 81:939-944.

14. Hernandez, L. A., M. B. Grisham, B. Twohig, K. E. Arfors, J. M. Harlan, and D. N. Granger. 1987. Role of neutrophils in ischemia-reperfusion-induced microvascular injury. Am. J. Physiol. 253 (Heart Circ. Physiol. 22):H699-H703.

15. Jaeschke, H., A. Farhood, and C. W. Smith. 1990. Neutrophils contribute to ischemia/reperfusion injury in rat liver in vivo. FASEB J. 4:3355-3359.
16. Simpson, P. J., and B. R. Lucchesi. 1987. Free radicals and myocardial ischemia and reperfusion injury. J. Lab. Clin. Med. 110:13-30.

17. Zimmerman, B. J., M. B. Grisham, and D. N. Granger. 1990. Role of oxidants in ischemia/reperfusion-induced granulocyte infiltration. Am. J. Physiol. 258 (Gastrointest. Liver Physiol. 21):G185-G190.

18. Linas, S. L., D. Whittenburg, and J. E. Repine. 1990. Role of xanthine oxidase in ischemia/reperfusion injury. Am. J. Physiol. 258 (Renal Fluid Electrolyte Physiol. 27):F711-F716.

19. Jaeschke, H., and A. Farhood. 1991. Neutrophil and kupffer cell-induced oxidant stress and ischemia-reperfusion injury in rat liver. Am. J. Physiol. 260 (Gastrointest. Liver Physiol. 23):G355-G362.

20. Petrone, W. F., D. K. English, K. Wong, and J. M. McCord. 1980. Free radicals and inflammation: superoxide-dependent activation of a neutrophil chemotactic factor in plasma. Proc. Natl. Acad. Sci. USA. 77:1159-1163.

21. Perez, H. D., B. B. Weksler, and I. M. Goldstein. 1980. Generation of a chemotactic lipid from acachidonic acid by exposure to a superoxide-generating system. Inflammation. 4:313-328.

22. Shingu, M., and M. Nobunaga. 1984. Chemotactic activity generated in human serum from the fifth component of complement by hydrogen peroxide. Am. J. Pathol. 117:201-206.

23. DeForge, L. E., and D. G. Remick. 1991. Kinetics of TNF, IL-6, and IL-8 gene expression in LPS-stimulated human whole blood. Biochem. Biophys. Res. Commun. 164:18-24.

24. DeForge, L. E., J. S. Kenney, M. L. Jones, J. S. Warren, and D. G. Remick. 1992. Biphasic production of IL-8 in LPS-stimulated human whole blood: separation of LPS- and cytokine-stimulated components using anti-TNF and anti-IL-1 antibodies. J. Immunol. 148:2133-2141.

25. DeForge, L. E., D. E. Tracey, J. S. Kenney, and D. G. Remick. 1992 Interleukin-1 receptor antagonist protein inhibits interleukin-8 expression in LPS-stimulated human whole blood. Am. J. Pathol. 140:1045-1054.

26. Hofsli, E., J. Lamvik, and J. Nissen-Meyer. 1988. Evidence that tumor necrosis factor (TNF) is not constitutively present in vivo: the association of TNF with freshly isolated monocytes reflects a rapid in vitro production. Scand. $J$. Immunol. 28:435-441.

27. Desch, C. E., N. L. Kovach, W. Present, C. Broyles, and J. M. Harlan. 1989. Production of human tumor necrosis factor from whole blood ex vivo. Lymphokine Res. 2:141-146.

28. Strieter, R. M., D. G. Remick, J. M. Ham, L. M. Colletti, J. P. Lynch III, and S. L. Kunkel. 1990. Tumor necrosis factor-alpha gene expression in human whole blood. J. Leukocyte Biol. 47:366-370.

29. Schumann, R. R., S. R. Leong, G. W. Flaggs, P. W. Gray, S. D. Wright, J. C. Mathison, P. S. Tobias, and R. J. Ulevitch. 1990. Structure and function of lipopolysaccharide binding protein. Science (Wash. DC). 249:1429-1432.

30. Wright, S. D., R. A. Ramos, P. S. Tobias, R. J. Ulevitch, and J. C. Mathison. 1990. CD14, a receptor for complexes of lipopolysaccharide (LPS) and LPS binding protein. Science (Wash. DC). 249:143-145.

31. Wharram, B. L., K. Fitting, S. L. Kunkel, D. G. Remick, S. E. Merritt, and R. C. Wiggins. 1991. Tissue factor expression in endothelial cell/monocyte cocultures stimulated by lipopolysaccharide and/or aggregated IgG: mechanisms of cell:cell communication. J. Immunol. 146:1437-1445.

32. Mosmann, T. 1983. Rapid colorimetric assay for cellular growth and survival: application to proliferation and cytotoxicity assays. J. Immunol. Methods. 65:55-63.

33. Espevik, T., and J. Nissen-Meyer. 1986. A highly sensitive cell line, WEHI 164 clone 13, for measuring cytotoxic factor/tumor necrosis factor from human monocytes. J. Immunol. Methods. 95:99-105.

34. Eskandari, M. K., D. T. Nguyen, S. L. Kunkel, and D. G. Remick. 1990. WEHI 164 subclone 13 assay for TNF: sensitivity, specificity, and reliability. Immunol. Invest. 19:69-79.

35. Aarden, L. A., E. R. DeGroot, O. L. Schaap, and P. M. Lansdorp. 1987. Production of hybridoma growth factor by human monocytes. Eur. J. Immunol. 17:1411-1416.

36. DeForge, L. E., and D. G. Remick. 1991. Sandwich ELISA for detection of picogram quantities of interleukin-8. Immun. Invest. 20:89-97.

37. Kenney, J. S., M. P. Masada, E. M. Eugui, B. M. Delustro, M. A. Mulkins, and A. C. Allison. 1987. Monoclonal antibodies to human recombinant interleukin 1 (IL $1 \beta$ ): quantitation of IL $1 \beta$ and inhibition of biological activity. $J$. Immunol. 138:4236-4242.

38. Matsushima, J., K. Morishita, T. Yoshimura, S. Lavu, Y. Kobayashi, W. Lew, E. Appella, H. F. Kung, E. J. Leonard, and J. J. Oppenheim. 1988. Molecular cloning of a human monocyte-derived neutrophil chemotactic factor (MDNCF) and the induction of MDNCF mRNA by interleukin 1 and tumor necrosis factor. J. Exp. Med. 167:1883-1893.

39. Tokunaga, K., H. Taniguchi, K. Yoda, M. Shimizu, and S. Sakiyama. 1986. Nucleotide sequence of a full-length cDNA for mouse cytoskeletal beta-actin mRNA. Nucleic Acids Res. 14:2829.

40. Repine, J. E., J. W. Eaton, M. W. Anders, J. R. Hoidal, and R. B. Fox. 1979. Generation of hydroxyl radical by enzymes, chemicals, and human phagocytes in vitro: detection with the anti-inflammatory agent, dimethyl sulfoxide. $J$. Clin. Invest. 64:1642-1651. 
41. Trice, J. M., and R. S. Pinals. 1985. Dimethyl sulfoxide: a review of its use in the rheumatic disorders. Semin. Arthritis Rheum. 15:45-60.

42. Jacob, S. W., and R. Herschler. 1986. Pharmacology of DMSO. Cryobioogy. 23:14-27.

43. Parker, N. B., E. M. Berger, W. E. Curtis, M. E. Muldrow, S. L. Linas, and J. E. Repine. 1986. Hydrogen peroxide causes dimethylthiourea consumption while hydroxyl radical causes dimethyl sulfoxide consumption in vitro. J. Free Radicals Biol. Med. 1:415-419.

44. Fox, R. B. 1984. Prevention of granulocyte-mediated oxidant lung injury in rats by a hydroxyl radical scavenger, dimethylthiourea. J. Clin. Invest. $74: 1456-1464$.

45. Cederbaum, A. I., E. Dicker, E. Rubin, and G. Cohen. 1979. Effect of thiourea on microsomal oxidation of alcohols and associated microsomal functions. Biochemistry. 18:1187-1191.

46. Freeman, B. A., and J. D. Crapo. 1982. Free radicals and tissue injury. Lab. Invest. 47:412-426.

47. Granger, D. N. 1988. Role of xanthine oxidase and granulocytes in ischemia-reperfusion injury. Am. J. Physiol. 255 (Heart Circ. Physiol. 24):H1269H1275.

48. McCord, J. M. 1987. Oxygen-derived radicals: a link between reperfusion injury and inflammation. Fed. Proc. 46:2402-2406.

49. Michelson, A. M., and K. Puget. 1980. Cell penetration by exogenous superoxide dismutase. Acta Physiol. Scand. 492(Suppl.):67-80.

50. Petkau, A., K. Kelly, W. S. Chelack, and C. Barefoot. 1976. Protective effect of superoxide dismutase on erythrocytes of $\mathrm{X}$-irradiated mice. Biochem Biophys. Res. Commun. 70:452-458.

51. Britigan, B. E., J. S. Serody, M. B. Hayek, L. M. Charniga, and M. S. Cohen. 1991. Uptake of lactoferrin by mononuclear phagocytes inhibits their ability to form hydroxyl radical and protects them from membrane autoperoxidation. J. Immunol. 147:4271-4277.

52. Halliwell, B. 1991. Reactive oxygen species in living systems: source, biochemistry, and role in human disease. Am. J. Med. 91:14S-22S.

53. Grisham, M. B., L. A. Hernandez, and D. N. Granger. 1986. Xanthine oxidase and neutrophil infiltration in intestinal ischemia. Am. J. Physiol. 251 (Gastrointest. Liver Physiol. 14):G567-G574.

54. Rankin, J. A., I. Sylvester, S. Smith, T. Yoshimura, and E. J. Leonard. 1990. Macrophages cultured in vitro release leukotriene $B_{4}$ and neutrophil attractant/activation protein (interleukin 8) sequentially in response to stimulation with lipopolysaccharide and zymosan. J. Clin. Invest. 86:1556-1564.
55. Collins, P. D., P. J. Jose, and T. J. Williams. 1991. The sequential generation of neutrophil chemoattractant proteins in acute inflammation in the rabbit in vivo. J. Immunol. 146:677-684.

56. Bautista, A. P., and J. J. Spitzer. 1990. Superoxide anion generation by in situ perfused rat liver: effect of in vivo endotoxin. Am. J. Physiol. 259 (Gastrointest. Liver Physiol. 22):G907-G912.

57. Bautista, A. P., A. Schuler, Z. Spolarics, and J. J. Spitzer. 1991. Tumor necrosis factor-alpha stimulates superoxide anion generation by perfused rat liver and Kupffer cells. Am. J. Physiol. 261:G891-G895.

58. Tsujimoto, M., S. Yokota, J. Vilcek, and G. Weissmann. 1986. Tumor necrosis factor provokes superoxide anion generation from neutrophils. Biochem. Biophys. Res. Commun. 137:1094-1100.

59. Warren, J. S., S. L. Kunkel, T. W. Cunningham, K. J. Johnson, and P. A. Ward. 1988. Macrophage-derived cytokines amplify immune complex-triggered $\mathrm{O}_{2}^{-}$responses by rat alveolar macrophages. Am. J. Pathol. 130:489-495.

60. Ginsburg, I., P. A. Ward, and J. Varani. 1989. Lysophosphatides enhance superoxide responses of stimulated human neutrophils. Inflammation. 13:163174.

61. Figari, I. S., N. A. Mori, and M. A. Palladino, Jr. 1987. Regulation of neutrophil migration and superoxide production by recombinant tumor necrosis factor- $\alpha$ and $-\beta$ : comparison to recombinant interferon- $\gamma$ and interleukin- $1 \alpha$. Blood. 70:979-984.

62. Matsubara, T., and M. Ziff. 1986. Increased superoxide anion release from human endothelial cells in response to cytokines. J. Immunol. 137:32953298.

63. Meier, B., H. H. Radeke, S. Selle, M. Younes, H. Sies, K. Resch, and G. G. Habermehl. 1989. Human fibroblasts release reactive oxygen species in response to interleukin-1 or tumor necrosis factor-alpha. Biochem. J. 263:539-545.

64. Ahmadzadeh, N., M. Shingu, and M. Nobunga. 1990. The effect of recombinant tumor necrosis factor-alpha on superoxide and metalloproteinase production by synovial cells and chondrocytes. Clin. Exp. Rheumatol. 8:387-391.

65. Sekizuka, E., J. N. Benoit, M. B. Grisham, and D. N. Granger. 1989. Dimethylsulfoxide prevents chemoattractant-induced leukocyte adherence. $\mathrm{Am}$. J. Physiol. 256 (Heart Circ. Physiol. 25):H594-H597.

66. Beilke, M. A., C. Collins-Lech, and P. G. Sohnle. 1987. Effects of dimethyl sulfoxide on the oxidative function of human neutrophils. J. Lab. Clin. Med. 110:91-96.

67. Palder, S. B., C. Wong, I. Hood, H. Wenger, J. A. Mannick, and R. H. Demling. 1985. Chemotactic activity of plasma and lung lymph in sheep with endotoxemia: effect of hydroxyl radical scavengers. J. Surg. Res. 38:162-172. 